\title{
Detection and Identification of Subcutaneous Adipose Tissue Protein Related to Obesity in New Zealand Obese Mouse
}

\author{
Hiroki TAKAHASHI, MaSAmichi OH-ISHI*, Hiroyuki SHIMIZU and MaSatomo MORI \\ First Department of Internal Medicine, Gunma University School of Medicine, Maebashi, Gunma 371-8511, Japan \\ * Department of Physics, School of Science, Kitasato University, 1-15-1 Kitasato Sagamihara, Kanagawa 228-8555, Japan
}

\begin{abstract}
New Zealand obese (NZO) mouse, a genetic model of obesity, shows hyperphagia, hyperinsulinemia and leptin resistance. We analyzed subcutaneous adipose tissue proteins in NZO mice with a two-dimensional gel electrophoresis technique followed by protein sequence analysis. NZO mice showed hyperinsulinemia and hyperleptinemia. Abdominal subcutaneous adipose tissue was inspected in NZO and C57BL/6J lean mice. Two-dimensional gel electrophoresis detected 4 spots which were obviously reduced in NZO mice. Those spots were p26, p19, p18 and p15. Internal sequences of the p 26 and p15 protein were homologous with those of carbonic anhydrase III, p19 was cytochrome b5, p18 was superoxide dismutase. Serum arachidonic acid level in NZO mice was lower by $80 \%$ of $\mathrm{C} 57 \mathrm{BL} / 6 \mathrm{~J}$ mice. The present study demonstrated the reduction of several enzymes related to lipid metabolism in NZO mice. These data raises the hypothesis that the supposed changes of membrane fluidity caused by altered membrane lipid content may involve central leptin resistance of this model of obesity.
\end{abstract}

Key Words: NZO mouse, Cytochrome $\mathrm{b}_{5}$, Superoxide dismutase, Carbonic anhydrase

(Endocrine Journal 48: 205-211, 2001)

GENETICALLY obese $(o b / o b)$ and diabetic $(d b / d b)$ mice show hyperphagia and hyperinsulinemia, but only genetically diabetic $(d b / d b)$ mice shows hyperleptinemia [1, 2]. Genetically obese $(o b / o b)$ mouse has a genetic defect in leptin production of adipose tissue, while peripheral administration of recombinant mouse leptin inhibits food intake and reduces excessive body weight gain [3, 4]. In contrast, genetically diabetic $(d b / d b)$ mouse has a mutation in leptin receptor, resulting in no response to peripherally administered leptin [2]. In those models of obesity, lipid metabolism is modulated in adipose tissue [5-7]. But since adipose tissue expresses short-form leptin receptor $(\mathrm{Ob}-\mathrm{Ra})$ [8], defects in leptin signaling to adipose tissues may affect lipid metabolism in both

Received: October 10, 2000

Accepted: January 16, 2001

Correspondence to: Hiroki TAKAHASHI, M.D., First Department of Internal Medicine, Gunma University School of Medicine, 3-39-15, Showa-machi, Maebashi, Gunma 3718511, JAPAN obese $(o b / o b)$ and diabetic $(d b / d b)$ mice.

Similarly with genetically obese $(o b / o b)$ and diabetic $(d b / d b)$ mice, New Zealand obese (NZO) mice, another genetic model of obesity [9], show hyperphagia, hyperinsulinemia, and leptin resistance. It is known that NZO mice have no genetic defects in adipose tissue leptin production and leptin receptor. However, NZO mice may show leptin resistance in the brain, since intracerebroventricular administration of recombinant mouse leptin inhibits food intake, in spite of no anorexigenic response to peripherally administered leptin [10]. It is supposed that leptin signaling is normally functioning in this model. To determine changes in lipid metabolism by obesity, we analyzed adipose tissue protein in NZO mice by using a two-dimensional electrophoresis technique 2DE [11]. 


\section{Materials and Methods}

\section{Animals}

Male New Zealand Obese (NZO) mice and $\mathrm{C} 57 \mathrm{BL} / 6 \mathrm{~J}$ mice as lean controls of NZO mice were purchased from M\&B A/S (Denmark). As the genotype of NZO mice is fixed by continuous inbreeding [12], metabolically normal controls with an identical genetic background are not available. Therefore we compared the obese NZO mice with lean C57BL/6J mice. All animals were fed standard diet and they had free access to food and water. They were housed in a temperature controlled room $\left(24 \pm 1^{\circ} \mathrm{C}\right)$ with a $14: 10 \mathrm{light} /$ dark cycle (illumination from $0500 \mathrm{~h}$ to $1900 \mathrm{~h}$ ).

\section{Two-dimensional gel electrophoresis (2-DE)}

All mice were decapitated at age of 20 weeks and, abdominal subcutaneous adipose tissue was immediately excised from $1000 \mathrm{~h}$ to $1200 \mathrm{~h}$ in a day. Excised adipose tissues were cut into the small pieces and kept frozen at $-80^{\circ} \mathrm{C}$ until analysis. A piece of frozen tissue about $100 \mathrm{mg}$ was homogenized with a Teflon glass homogenizer in a 10 -fold volume of extraction medium comprised of $5 \mathrm{M}$ urea, $1 \mathrm{M}$ thiourea solution containing $0.5 \% \quad 2$-mercaptoethanol and $0.1 \mathrm{mM}$ $\mathrm{N}^{\alpha}$-tosyl-L-lysylchloromethane hydrochloride. The homogenate was centrifuged with a TOMY TMA-6 rotor at $15,000 \mathrm{rpm}$ for $20 \mathrm{~min}$, and the clear supernatant was subjected to the first-dimension isoelectric focusing of 2-DE. We performed the 2-DE according to our procedure [11]. The isoelectric focusing agarose gel for the first dimension electrophoresis was $260 \mathrm{~mm}$ in length and $3 \mathrm{~mm}$ in diameter in a glass tube. The slab gel for the second dimension electrophoresis was $15 \%$ polyacrylamide gel and was $195 \mathrm{~mm}$ in width, $120 \mathrm{~mm}$ in height, and $1.5 \mathrm{~mm}$ in thickness. The isoelectric focusing was conducted at $600 \mathrm{~V}$ for 18 hours at $4^{\circ} \mathrm{C}$, and the second dimension SDS electrophoresis was carried out according to the stacking system of Laemmli [13]. Five hundred $\mu \mathrm{g}$ of the protein extract was applied for the first dimension isoelectric focusing. The slab gels after the second dimension electrophoresis were stained with Phast-Gel Blue R (Coomassie brilliant blue $\mathrm{R}$ 350: Pharmacia Biotech AB, Uppsala, Sweden).
Protein content determination from electrophoretic patterns

A Coomassie-stained 2-DE gel was interposed between two wet cellophane sheets and stretched with two styrene plastic frames to be dried in a draft chamber at $60^{\circ} \mathrm{C}$ for 2 hours. To precisely compare protein constituents of the NZO and C57BL6J tissues, we repeated 2-DE three times; the first was the C57BL6J tissue extract, the second the NZO one, and the third a 1:1 mixture of the two. The third 2-DE pattern was quite important, since without it we were unable to discriminate whether a pair of C57BL6J and NZO spots located very close to each other in the first two 2-DE patterns were identical or not. It also worked for our identifying proteins in the NZO mouse, which are normal in 2-DE position but abnormal in protein content. When we look carefully at either of the first two 2-DE patterns, we can discern which protein is more and which is less. When a protein spot in the 2-DE pattern of C57BL6J is denser than a nearby protein spot, but less dense in the NZO pattern, that spot would be a candidate for an abnormal protein. We then look for a corresponding spot in the third 2-DE patterns and compare the spot density with nearby spot densities. If the comparison comes up to our expectation that the 1:1 mixture 2-DE patterns is between the first two, the candidate protein in the NZO tissue would likely be abnormal in protein content.

\section{In-gel digestion of proteins for internal amino acid sequencing}

A protein spot that contained a target protein was cut out from a 2-DE gel and subjected to $\mathrm{NH}_{2}$-terminal amino acid sequence analysis (HPG1005A Protein Sequencing Systems; Hewlett-Packard Co., Palo Alto, CA). Amino acid sequence was performed by the in-gel digestion method described by Rosenfeld et al. [14].

\section{Assay}

$\mathrm{NZO}$ and $\mathrm{C} 57 \mathrm{BL} / 6 \mathrm{~J}$ mice were decapitated and blood samples were collected. Serum was obtained after centrifugation and stored at $-30^{\circ} \mathrm{C}$. Two samples were combined as a sample. Serum immunoreactive insulin (IRI) concentrations were as- 
sayed by a radioimmunoassay using Phadeceph Insulin Kit (Pharmacia Japan, Tokyo, Japan). Serum immunoreactive leptin (IRL) concentrations were assayed by a radioimmunoassay using Mouse Leptin RIA Kit (Linco Research, Inc., St. Charles, MO, U.S.A.). Serum glucose concentrations were determined by automatic analyzer using glucose oxidase method. In addition, we examined changes in serum fatty acid composition of these animals by gas-liquid chromatography method.

\section{Statistical analysis}

All data are expressed as mean \pm SE. Statistical analysis was performed by analysis of variance (ANOVA), followed by Student's t-test for the individual comparisons of the means.

\section{Results}

Circulating glucose, insulin and leptin levels in $\mathrm{NZO}$ and $\mathrm{C} 57 \mathrm{BL} / 6 \mathrm{~J}$

Circulating glucose, insulin and leptin levels are summarized in Table 1. There was no significant difference in serum glucose concentrations. Serum IRI concentrations were significantly higher in NZO mice than in C57BL/6J mice. Serum IRL concentrations were also increased in NZO mice.

\section{Protein content disparity and amino-acid se- quences in the NZO and C57BL/6J abdominal subcutaneous adipose tissue}

Fig. 1 shows 2-DE patterns of abdominal subcutaneous adipose tissue extracts of the C57BL/6J (A), NZO (B) mice and a 1:1 mixture of both mice (C). A part of each panel of Fig. 1 is expanded and

Table 1. Circulating glucose, insulin and leptin levels in $\mathrm{C} 57 \mathrm{BL} / 6 \mathrm{~J}$ and NZO mice.

\begin{tabular}{lccc}
\hline & $\begin{array}{c}\text { Glucose } \\
(\mathrm{mg} / \mathrm{dl})\end{array}$ & $\begin{array}{c}\text { IRI } \\
(\mu \mathrm{U} / \mathrm{ml})\end{array}$ & $\begin{array}{c}\text { IRL } \\
(\mathrm{ng} / \mathrm{ml})\end{array}$ \\
\hline $\mathrm{C} 57 \mathrm{BL} / 6 \mathrm{~J}$ & $179.8 \pm 3.7$ & $13.0 \pm 1.7$ & $3.08 \pm 0.25$ \\
$\mathrm{NZO}$ & $184.6 \pm 3.4$ & $37.0 \pm 3.6^{\mathrm{a}}$ & $9.53 \pm 0.79^{\mathrm{a}}$ \\
\hline
\end{tabular}

${ }^{a} \mathrm{p}<0.01$ vs. C57BL $/ 6 \mathrm{~J}$ mice $\mathrm{n}=5$ each shown in Fig. 2. Each protein spot in Fig. 1 is named by the molecular weight in the 2-DE pattern, i.e., the protein spot in Fig. 1 denoted as p26 is $26 \mathrm{KDa}$ in apparent molecular weight. The C57BL/6J and NZO patterns reveal general similarities, but we can still identify the differences in several spots. Four dense spots named as p26, p19, p18 and p15 are faint in the NZO tissue. Since these proteins were supposed to decrease in NZO mice, they were analyzed for their amino acid sequences.

We analyzed ten amino acid sequences from $\mathrm{N}$ terminal of four selected protein obtained from the spots mentioned above by 2-DE analysis. Table 2 shows the amino acid sequences of the four spots together with the names of homologous proteins identified in the protein identification resources database. Internal sequences of the p26 and p15 protein were homologous with those carbonic anhydrase III, p19 was cytochrome $\mathrm{b}_{5}$, and p18 was superoxide dismutase.

\section{Serum fatty acid composition}

Table 3 demonstrated serum fatty acid composition of C57BL/6J and NZO mice. The ratio of unsaturated fatty acids tended to be higher in the sera of NZO mice than in C57BL/6J mice. Serum arachidonic acid level of NZO mice was reduced by $80 \%$ of C57BL/6J mice.

\section{Discussion}

The present study reconfirmed that NZO mice show hyperinsulinemia and hyperleptinemia. We analyzed abdominal subcutaneous adipose tissue protein constituents in C57BL/6J and NZO mice. Four spots were obviously decreased in NZO mice. The protein analysis of $\mathrm{N}$-terminal ten amino acid sequences showed that those proteins are carbonic anhydrase III, cytochrome $b_{5}$ and superoxide dismutase.

First, we found that cytochrome $b_{5}$ content was reduced in adipose tissue of NZO mice. Cytochrome $\mathrm{b}_{5}$ in rat liver microsomes acts as an intermediate electron carrier which passes reducing equivalents from NADH, NADPH and ascorbate to the cyanide-sensitive factor where fatty acid desaturation takes place, and plays a similar role in fatty acid 


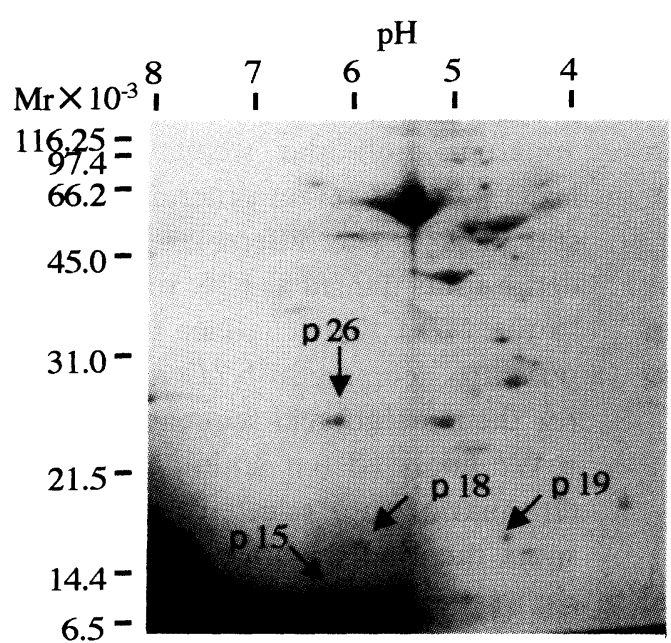

A

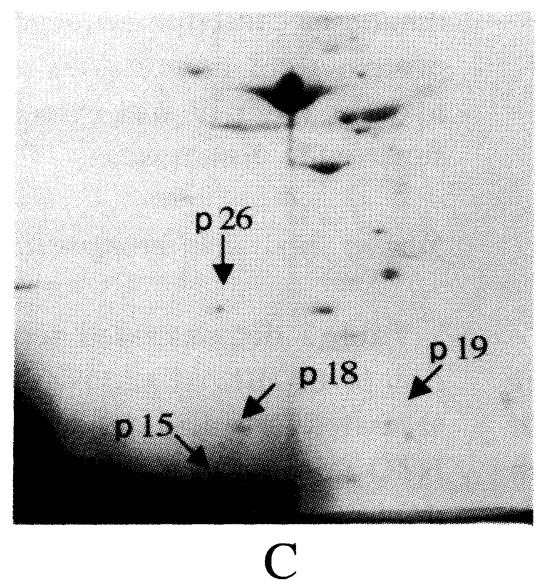

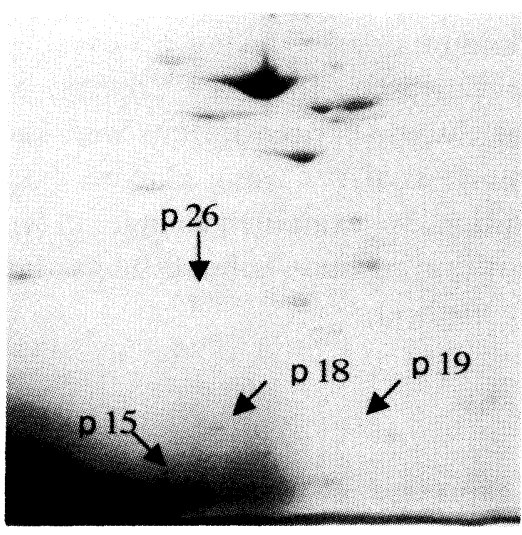

B

Fig. 1. Comparison of 2-DE patterns of the C57BL/6J and NZO abdominal subcutaneous adipose tissue extracts. The gels were stained PhastGel Blue R. A: 2-DE patterns of a C57BL/6J abdominal subcutaneous adipose tissue extract, B: NZO tissue extracts, C: a 1:1 mixture of the two. Spots are labeled by apparent molecular weight.

desaturation in epididymal adipose tissue [15]. In streptozotocin-induced diabetes rat, cytochrome $b_{5}$ level of liver were elevated and returned to normal after insulin treatment [16, 17], suggesting that hyperinsulinemia is related to the decrease of liver cytochrome $b_{5}$ content in NZO mice. In mice, feeding of fat-free diet significantly reduced cytochrome $b_{5}$ in liver, but increased it in lung [18]. It is supposed that cytochrome $b_{5}$ is related to fat intake [19].

However, there have been few reports on the changes of adipose tissue cytochrome $b_{5}$ contents in models of obesity. No significant effect on cytochrome $b_{5}$ content and $\mathbf{P} 450$ reductase activity was seen in obese rats induced by overfeeding had [20], nor were there any significant differences in the cytochrome $b_{5}$ contents of ventromedial hypothalamus lesioned rats [21]. Therefore, it is possible that the observed reduction of cytochrome $b_{5}$ content can't be explained by obesity alone and may be specific for NZO mice.

Cytochrome $b_{5}$ reductase is detected not only in liver, but also in adipose tissue microsomes [22]. In a case of generalized deficiency of cytochrome $b_{5}$ reductase in congenital methemoglobinemia, there was a decrease in total unsaturated fatty acids and an increase in palmitic acid, indicating an undeveloped pattern of fatty acid composition in adipose tissue, and the proportions of arachidonic acids (AA) were decreased to less than half of normal levels [23]. Mammalian membrane polyunsaturated fatty acid composition modifies membrane fluidity and its function [24]. Exposure of cultured cerebromicrovascular endothelial cells to AA increases membrane fluidity, while addition of $\mathrm{AA}$ and $\mathrm{H}_{2} \mathrm{O}_{2}$ leads to persistent alteration of endothelial cell permeability [25]. Arachidonic acid composition was reduced in 


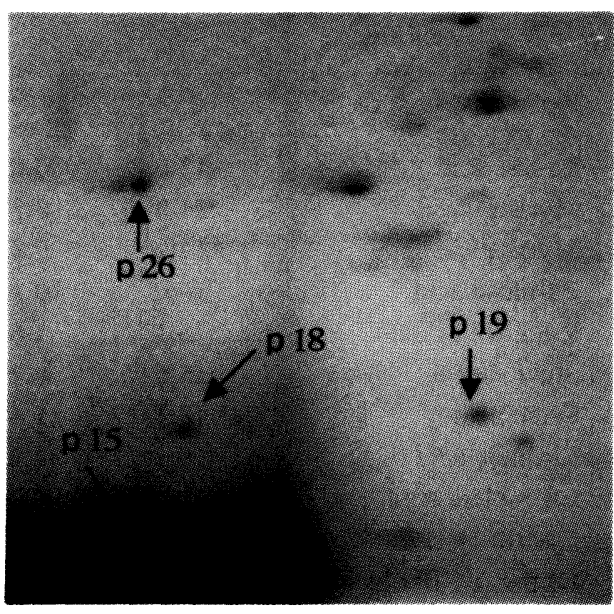

A

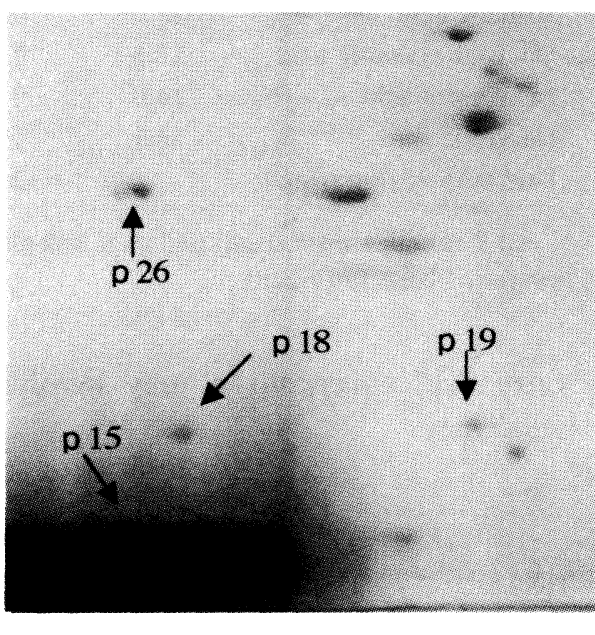

C

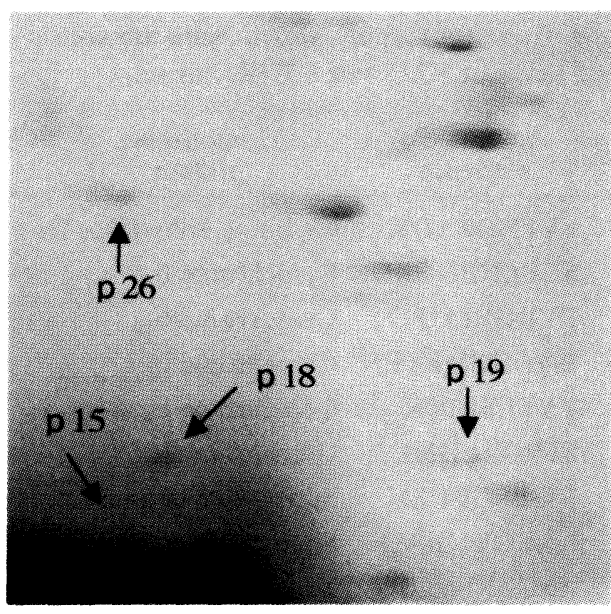

B

Fig. 2. Expanded view of the area from $15 \mathrm{KDa}$ to $26 \mathrm{KDa}$ of Fig. 1, where spots are too small to be clearly seen. A: 2-DE patterns of a C57BL/6J abdominal subcutaneous adipose tissue extract, B: NZO tissue extracts, C: a 1:1 mixture of the two.

the serum of NZO mice. The reduction of cytochrome $b_{5}$ in NZO mice may modify the fatty acid composition of body lipids as well as brain lipids. The changes of brain lipid contents, such as reduction of AA content, may modulate membrane composition and membrane fluidity of brain microvessels, possibly involving central leptin resistance of this animal [10].

In addition, we found the reduction of two more enzymes in NZO mice, carbonic anhydrase III (CAIII) and superoxide dismutase. CAIII is a major constituent of murine adipose tissue and located in the perinuclear and peripheral cytoplasm bordering fat droplets [26]. While CAIII is highly expressed in red skeletal muscle, it has been reported that CAIII is low in $o b / o b$ and MSG-obese mice. This decrease in
CAIII expression was unique to adipose tissue [27]. It is suggested that the reduction of CAIII levels may be correlated with the degree of obesity. Since CAIII is low in insulin-treated 3T3 adipocytes [28], the obesity-related decrease in CAIII may be associated with hyperinsulinemia in obesity. Since NZO mice also show marked hyperinsulinemia as shown in Table 1, the observed reduction of CAIII should be attributable to hyperinsulinemia accompanied with obesity.

Regarding the other enzym, superoxide dismutase (SOD), manganese (Mn) SOD activities in brown adipose tissue of $o b / o b$ mice are lower and adrenalectomy failed to restore MnSOD activities, suggesting that glucocorticoid is not related to the reduction of SOD activities in $o b / o b$ mice [29]. Lower SOD 
Table 2. N-terminal amino-acid sequences from the proteins obtained from four spots which were obviously different between NZO and C57BL /6J mice.

\begin{tabular}{ccll}
\hline Source & Fraction & $\begin{array}{c}\text { Amino-acid } \\
\text { sequence }\end{array}$ & \multicolumn{1}{c}{$\begin{array}{c}\text { Homologous } \\
\text { protein }\end{array}$} \\
\hline p26 & 1 & VVFDDTYDR & Carbonic anhydrase III \\
p19 & 1 & FLEEHPGGEE & $\begin{array}{l}\text { Cytochrome } b_{5} \\
\end{array}$ \\
& 2 & TYIIGELHPD & Cytochrome $b_{5}$ \\
& 3 & EQAGGDATEN & Cytochrome $b_{5}$ \\
& 4 & YYTLEEIQK & Cytochrome $b_{5}$ \\
p18 & 1 & VISLSGEHSI & Superoxide dismutase \\
& & LACGVIGIAQ & Superoxide dismutase \\
& 2 & ASGEPVVLSG & Superoxide dismutase \\
p15 & 1 & QFHLHWGSSD & Carbonic anhydrase III \\
& 2 & HDPSLQPWSA & Carbonic anhydrase III \\
\hline
\end{tabular}

activities in liver was eliminated by food restriction, but not in kidney [30]. The observed reduction of SOD content may be related to hyperphagia associated with obesity.

The present study demonstrated the reduction of several enzymes related to lipid metabolism in NZO mice. The reduction of cytochrome $b_{5}$ may be specific for NZO mice and the subsequent changes of
Table 3. Serum fatty acid composition in NZO and C57BL $16 \mathrm{~J}$ mice.

\begin{tabular}{lccc}
\hline Fatty acid & & C57BL/6J & NZO \\
\hline Lauric acid & $12: 0$ & 0.02 & 0.06 \\
Myristic acid & $14: 0$ & 0.31 & 0.35 \\
Myristoleic acid & $14: 1$ & 0.41 & 0.23 \\
Palmitic acid & $16: 0$ & 20.16 & 21.45 \\
Palmitoleic acid & $16: 1$ & 3.66 & 3.66 \\
Stearic acid & $18: 0$ & 6.77 & 6.68 \\
Oleic acid & $18: 1$ & 15.49 & 18.26 \\
Linoleic acid & $18: 2$ & 32.66 & 31.08 \\
$\alpha$-Linoleic acid & $18: 3$ & 0.92 & 0.92 \\
Gondoic acid & $20: 1$ & 0.85 & 0.93 \\
Dihomo- $\gamma$ linolenic acid & $20: 3$ & 1.38 & 1.09 \\
Arachidonic acid & $20: 4$ & 7.25 & 5.84 \\
Eicosapentaenoic acid & $20: 5$ & 1.97 & 1.98 \\
Behenic acid & $22: 0$ & 0.28 & 0.27 \\
Docosahexaenoic acid & $22: 6$ & 7.32 & 6.55 \\
Lignoceric acid & $24: 0$ & 0.18 & 0.14 \\
Nervonic acid & $24: 1$ & 0.40 & 0.24 \\
Unsaturated/Saturated & & 2.609 & 2.454 \\
\hline
\end{tabular}

All 9 samples were combined as a sample. Values were $\%$ weight of each fatty acid.

fatty acid composition may involve central leptin resistance.

\section{References}

1. Coleman DL (1985) Increased metabolic efficiency in obese mutant mice. Int J Obes 2: 69-73.

2. Halaas JL, Gajiwala KS, Maffei M, Cohen SL, Chait BT, Rabinowitz D, Lallone RL, Burley SK, Friedman JM (1995) Weight-reducing effects of the plasma protein encoded by the obese gene. Science 269: 543-546.

3. Zhang $Y$, Proenca R, Maffei M, Barone M, Leopold L, Friedman JM (1994) Positional cloning of the mouse obese gene and its human homologue. Nature 372: 425-432.

4. Pelleymounter MA, Cullen MJ, Baker MB, Hecht R, Winters D, Boone T, Collins F (1995) Effects of the obese gene product on body weight regulation in ob/ob mice. Science 269: 540-543.

5. Kaplan ML, Leveille GA (1981) Development of lipogenesis and insulin sensitivity in tissues of the ob/ob mouse. Am J Physiol 240(2): E101-107.

6. Memon RA, Fuller J, Moser AH, Smith PJ, Grunfeld C, Feingold KR (1999) Regulation of putative fatty acid transporters and Acyl-CoA synthetase in liver and adipose tissue in ob/ob mice. Diabetes 48: 121-
127.

7. Berk PD, Zhou S, Kiang C, Stump DD, Fan X, Bradbury MW (1999) Selective up-regulation of fatty acid uptake by adipocytes characterizes both genetic and diet-induced obesity in rodents. $J$ Biol Chem 274: 28626-28631.

8. Lollmann B, Gruninger S, Stricker KA, Chiesi M (1997) Detection and quantification of the leptin receptor splice variants $\mathrm{Ob}-\mathrm{Ra}, \mathrm{b}$, and, e in different mouse tissues. Biochem Biophys Res Commun 238: 648-652.

9. Igel M, Becker W, Herberg L, Joost HG (1997) Hyperleptinemia, leptin resistance, and polymorphic leptin receptor in the New Zealand obese mouse. Endocrinology 138: 4234-4239.

10. Halaas JL, Boozer C, Blair WJ, Fidahusein N, Denton DA, Friedman JM (1997) Physiological response to long-term peripheral and central leptin infusion in lean and obese mice. Proc Natl Acad Sci USA 94: 8878-8883.

11. Oh-Ishi M, Hirabayashi T (1989) Comparison of 
protein constituents between atria and ventricles from various vertebrates by two-dimensional gel electrophoresis. Comp Biochem Physiol B 92: 609-617.

12. Bielschowsky M, Goodall CM (1970) Origin of inbred NZ mouse strains. Cancer Res 30: 834-836.

13. Laemmli UK (1970) Cleavage of structural proteins during the assembly of the head of bacteriophage T4. Nature 227: 680-685.

14. Rosenfeld J, Capdevielle J, Guillemot JC, Ferrara P (1992) In-gel digestion of proteins for internal sequence analysis after one- or two-dimensional gel electrophoresis. Anal Biochem 203: 173-179.

15. Oshino N, Imai Y, Sato R (1971) A function of cytochrome $b_{5}$ in fatty acid desaturation by rat liver microsomes. J Biochem Tokyo 69: 155-167.

16. Eck MG, Wynn JO, Carter WJ, Faas FH (1979) Fatty acid desaturation in experimental diabetes mellitus. Diabetes 28: 479-485.

17. Bitar M, Weiner M (1984) Diabetes-induced metabolic alterations in heme synthesis and degradation and various heme-containing enzymes in female rats. Diabetes 33: 37-44.

18. Koul IB, Koul A, Gandhi RK, Sharma RR, Khanduja KL (1990) Differential effects of fat deficiency on hepatic and pulmonary drug metabolizing enzymes in rat and mouse. Biochem Int 20: 979-989.

19. Ammouche A, Dinh L, Youyou A, Clement M, Bourre JM (1993) Rate of alteration of hepatic mixed-function oxidase system in rats fed different dietary fats. Biochem Cell Biol 71: 530-537.

20. Raucy JL, Lasker JM, Kraner JC, Salazar DE, Lieber CS, Corcoran GB (1991) Induction of cytochrome P450IIE1 in the obese overfed rat. Mol Pharmacol 39: 275-280.

21. Inui $Y$, Kawata $S$, Matsuzawa $Y$, Tokunaga $K$, Tamura S, Fukuda K, Maeda Y, Tarui S (1991)
Selective increase in cytochrome P450 content in hepatic microsomes from rats with ventromedial hypothalamic lesions. Int J Obes 15: 221-225.

22. Seifried HE, Gaylor JL (1976) Investigation of microsomal oxygenases of biosynthetic processes. StearylCoA desaturase of adipose tissue and liver. $\mathrm{J} \mathrm{Biol}$ Chem 251: 7468-7473.

23. Hirono $H$ (1983) Adipose fatty acid composition in a case of generalized deficiency of cytochrome $b_{5}$ reductase in congenital methemoglobinemia with mental retardation. Tohoku J Exp Med 140: 391-394.

24. Stubbs CD, Smith AD (1984) The modification of mammalian membrane polyunsaturated fatty acid composition in relation to membrane fluidity and function. Biochim Biophys Acta 779: 89-137.

25. Villacara A, Zanchin G, Spatz M (1990) Evaluation of membrane fluidity in cerebral microvasculature. Microcirc Endothelium Lymphatics 6: 45-65.

26. Spicer SS, Ge ZH, Tashian RE, Hazen MD, Schulte BA (1990) Comparative distribution of carbonic anhydrase isozymes III and II in rodent tissues. $A m J$ Anat 187: 55-64.

27. Stanton LW, Ponte PA, Coleman RT, Snyder MA (1991) Expression of CA III in rodent models of obesity. Mol Endocrinol 5: 860-866.

28. Lynch CJ, Hazen SA, Horetsky RL, Carter ND, Dodgson SJ (1993) Differentiation-dependent expression of carbonic anhydrase II and III in 3T3 adipocytes. Am J Physiol 265(1): C234-243.

29. Begin HN, Deeks JR (1987) Hypercorticism and manganese metabolism in brown adipose tissue of the obese mouse. J Nutr 117: 1708-1714.

30. Prohaska JR, Wittmers LJ, Haller EW (1988) Influence of genetic obesity, food intake and adrenalectomy in mice on selected trace element-dependent protective enzymes. $J$ Nutr 118: 739-746. 